\title{
EVIDENCE AND IMPLICATIONS OF ZIPF'S LAW FOR INTEGRATED ECONOMIES
}

\author{
HARRY P. BOWEN \\ HARIS MUNANDAR \\ JEAN-MARIE VIAENE
}

CESIFO WORKING PAPER NO. 1743

CAtegory 5: Fiscal Policy, Macroeconomics AND GROWTH JUNE 2006

Presented at CESifo Area Conference on Global Economy, April 2006

\footnotetext{
An electronic version of the paper may be downloaded

- from the SSRN website:

www.SSRN.com

- from the RePEc website:

Www.RePEC.org

- from the CESifo website:

www.CESifo-group.de
} 


\title{
EVIDENCE AND IMPLICATIONS OF ZIPF’S LAW FOR INTEGRATED ECONOMIES
}

\begin{abstract}
This paper considers the distribution of output and productive factors among members of a fully integrated economy (FIE). We demonstrate that each member's shares of total output and of total factors will be equal. This implies that growth in shares is random. If output and factor shares evolve as reflective geometric Brownian motion, then limiting distribution of these shares will exhibit Zipf's law. Our empirics support Zipf's law for U.S. states and for E.U. countries. These findings imply that models characterizing growth of members within an FIE should embody a key assumption: growth process of shares is random and homogeneous.

JEL Code: E13, F15, F21, F22, O57.
\end{abstract}

Keywords: growth, economic integration, factor price equalization, Zipf's law.

Harry P. Bowen

Vlerick Leuven Gent Management School Vlamingenstraat 83 3000 Leuven

Belgium

harry.bowen@vlerick.be
Haris Munandar

Erasmus University Rotterdam

P.O. Box 1738

3000 DR Rotterdam

The Netherlands

munandar@few.eur.nl

\author{
Jean-Marie Viaene \\ Erasmus University Rotterdam \\ P.O. Box 1738 \\ 3000 DR Rotterdam \\ The Netherlands \\ viaene@few.eur.nl
}

May 2006

We thank Xavier Gabaix for helpful comments and clarifying discussions. We also benefited from comments from Joe Francois, Charles van Marrewijk, Enrico Pennings, participants of the CESifo Area Conference on Global Economy 2006 (Munich), the European Trade Study Group 2005 (Dublin) and seminar participants at Erasmus University and the Tinbergen Institute. 


\section{Evidence and Implications of Zipf's Law for Integrated Economies}

The number of regional trade agreements has increased continuously since the early 1990s and many new initiatives for special association agreements are currently being negotiated (see WTO website). Institutional arrangements under which countries open their borders differ in reality. Most agreements are designed to increase international trade between markets but a few, like the European Union, also allow greater mobility of productive factors within the integrated area. In the limit, such integration would be represented by a fully integrated economy (FIE) in which there is free mobility of goods and factors among FIE members together with complete harmonization of economic and social policies.

While prior work has demonstrated the potentially important role of trade ${ }^{1}$ and factor mobility $^{2}$ as influences on economic growth, less attention has been given to the question of how trade and factor mobility impact the distribution of output across members of a FIE, and hence how these influences affect the relative economic position of members. Apart from being simply a question of distributional consequences, analysis of this question has important implications for the nature of models that can be used to characterize the growth processes of FIE members. Specifically, as we will show in this paper, the distribution of output and factor shares across FIE members can be expected to conform to a rank-share distribution that exhibit Zipf's law, which indicates a specific relationship between the rank

\footnotetext{
${ }^{1}$ An extensive body of work has explored the role of international trade and of factor mobility as mechanisms generating endogenous economic growth. For example, Grossman and Helpman (1991) show that trade generally enhances growth, particularly when it facilitates the international transmission of knowledge. Similarly, Rivera-Batiz and Romer (1991) show that increased trade due to economic integration may have both level and growth effects depending upon the processes by which R\&D and information flow across borders. Devereux and Lapham (1994) extend Rivera-Batiz and Romer's model to show that, even without knowledge flows, the balanced growth rate when there is free trade in goods alone exceeds that in autarky, provided that initial levels of national income differ across countries.

${ }^{2}$ For example, Baldwin and Martin (2004) examine the relationship between growth and the agglomeration of economic activity and find that it depends crucially on the extent of capital mobility between regions. Similarly, Viaene and Zilcha (2002) show that while complete capital market integration among countries has a positive effect on outputs, it does not raise long-run growth rates above autarky values. Instead, these growth rates are affected only by parameters that describe the accumulation of human capital.
} 
and value of a variable. This result implies that models used to characterize the growth of members within an FIE must embody a key assumption: that the underlying growth process of shares is random and homogeneous across members.

Country shares of regional (or world) output, or shares of a region's total supplies of productive factors, have become increasingly important constructs in the international trade literature (e.g., Bowen et al., 1987; Helpman and Krugman, 1985; Leamer, 1984; Viaene and Zilcha, 2002). In this regard, below we first demonstrate that, within an FIE, each member's share of total FIE output will equal its shares of total FIE stocks of each productive factor (i.e., physical capital and human capital). If economic policies are largely harmonized across members then this equal-share property implies that the growth in any member's shares of FIE output and factor stocks can be taken to be a random outcome. Following Gabaix (1999a), if output and factor shares evolve as geometric Brownian motion with a lower bound, then the limiting distribution of these shares will exhibit Zipf's law. Given this result, we then show that the limiting values of each FIE member's output and factor shares are completely determined once the number of FIE members is specified.

Given the theoretical expectation of Zipf's law for output and factor shares, we empirically examine for this law within two (presumably) integrated economies: the 51 U.S. states and 14 countries of the European Union (E.U.). The data generally cover the period from 1965 to 2000. Our empirical results convincingly support Zipf's law for U.S. states and for E.U. countries.

\section{Equality of Output and Factor Shares in Integrated Economies}

To demonstrate the equality of output and factor shares for each member of a fully integrated economy we consider an integrated economy that consists of $m=1, \ldots, M$ members, each producing a single good by means of a constant return to scale production function of the form: 


$$
Y_{m t}=F\left(K_{m t}, H_{m t}\right) \quad m=1, \ldots, M
$$

where $Y_{m t}$ is the level of output, $K_{m t}$ the stock of physical capital, and $H_{m t}$ the stock of human capital, all for country $m$ at time $t$. The production function is assumed to satisfy all the neoclassical assumptions including diminishing marginal productivity with respect to each factor. For ease of exposition, the production function is assumed to take the Cobb Douglas form: ${ }^{3}$

$$
Y_{m t}=A_{m t} K_{m t}^{\alpha_{m}} H_{m t}^{1-\alpha_{m}} \quad m=1, \ldots, M
$$

where $A_{m t}$ is a scale parameter and $\alpha_{m}$ is capital's share of total output. If physical capital and labor are perfectly mobile between the $M$ economies then we would expect the marginal product of each factor to be equal. Barriers to capital mobility (e.g. corporate income tax differentials, capital controls) or labor mobility (e.g. language, different pension systems) would instead create persistent differences in factor rates of returns between members. Consider one reference member of this integrated economy that, without loss of generality, we take to be country $i$. Let $\lambda_{m t}^{k}$ and $\lambda_{m t}^{h}$ define the proportional difference in rates of return to physical capital and to human capital between any country $m$ and reference country $i$. The relation between rates of return to physical capital in the integrated economy can then be written as:

$$
v_{1} \lambda_{1 t}^{k} \frac{Y_{1 t}}{K_{1 t}}=\ldots=\frac{Y_{i t}}{K_{i t}}=\ldots=v_{M} \lambda_{M t}^{k} \frac{Y_{M t}}{K_{M t}}
$$

where $v_{m}=\alpha_{m} / \alpha_{i}$, implying $v_{m}=1$ when $\alpha_{m}=\alpha_{i}(m=1, \ldots, M)$. Note that for $m=i, \lambda_{i t}^{k}=1$ and $v_{i}=1$. Likewise, the relation between rates of return to human capital can be written:

$$
\omega_{1} \lambda_{1 t}^{h} \frac{Y_{1 t}}{H_{1 t}}=\ldots=\frac{Y_{i t}}{H_{i t}}=\ldots=\omega_{M} \lambda_{M t}^{h} \frac{Y_{M t}}{H_{M t}}
$$

\footnotetext{
${ }^{3}$ The Cobb-Douglas specification has wide empirical support (e.g., Mankiw et al., 1992). The analysis can be extended to the case where the production function has the constant elasticity of substitution (C.E.S.) form.
} 
where $\omega_{m}=\left(1-\alpha_{m}\right) /\left(1-\alpha_{i}\right)$, implying $\omega_{m}=1$ when $\alpha_{m}=\alpha_{i}(m=1, \ldots, M)$. Note that for $m$ $=i, \omega_{i}=1$ and $\lambda_{i t}^{h}=1$. The ratio of (3) to (4) gives the following relationship between ratios of human to physical capital:

$$
\eta_{1} \lambda_{1 t} \frac{H_{1 t}}{K_{1 t}}=\ldots=\frac{H_{i t}}{K_{i t}}=\ldots=\eta_{M} \lambda_{M t} \frac{H_{M t}}{K_{M t}}=\frac{\sum_{m=1}^{M} \eta_{m} \lambda_{m t} H_{m t}}{\sum_{m=1}^{M} K_{m t}}
$$

where

$$
\begin{aligned}
& \eta_{m}=v_{m} / \omega_{m}=\alpha_{m}\left(1-\alpha_{i}\right) / \alpha_{i}\left(1-\alpha_{m}\right), \text { implying } \eta_{m}=1 \text { when } \alpha_{m}=\alpha_{i} ; \\
& \lambda_{m t}=\lambda_{m t}^{k} / \lambda_{m t}^{h}, \text { implying } \lambda_{m t}=1 \text { when } \lambda_{m t}^{k}=\lambda_{m t}^{h} .
\end{aligned}
$$

Like in (5), we can rewrite (3) as:

$$
v_{1} \lambda_{1 t}^{k} \frac{Y_{1 t}}{K_{1 t}}=\ldots=\frac{Y_{i t}}{K_{i t}}=\ldots=v_{M} \lambda_{M t}^{k} \frac{Y_{M t}}{K_{M t}}=\frac{\sum_{m=1}^{M} v_{m} \lambda_{m t}^{k} Y_{m t}}{\sum_{m=1}^{M} K_{m t}}
$$

Combining (5) and (6) yields the following relationship between output and factor shares for reference member $i$ of the integrated economy:

$$
\frac{Y_{i t}}{\sum_{m=1}^{M} v_{m} \lambda_{m t}^{k} Y_{m t}}=\frac{K_{i t}}{\sum_{m=1}^{M} K_{m t}}=\frac{H_{i t}}{\sum_{m=1}^{M} \eta_{m} \lambda_{m t} H_{m t}} \quad i=1, \ldots, M
$$

We term equation (7) the "equal-share" relationship. This relationship determines the distribution of output and the distribution of factors across $M$ members of an integrated economy. Expression (7) contains both observable variables $\left(Y_{m t}, K_{m t}, H_{m t}\right)$ and unknown parameters $\left(\alpha_{m}, \lambda_{m}^{k}, \lambda_{m}^{h}\right)$. Differences in technology or factor market imperfections imply a multiplicative rescaling of the observable variables that is different for each ratio. For example, a difference in $\alpha$ 's leaves the observed values (and share) of physical capital unaffected but transforms the observed values of output and human capital in different ways 
(through $v_{m}$ and $\eta_{m}$ respectively). If we assume that the $M$ members of the integrated economy share the same technology $\left(\eta_{m}=v_{m}=\omega_{m}=1\right)$, and that there is costless (perfect) mobility of factors $\left(\lambda_{m t}^{k}=\lambda_{m t}^{h}=1\right)$, then we obtain the simplest expression of the equal-share relationship for any member $i$ :

$$
\frac{Y_{i t}}{\sum_{m=1}^{M} Y_{m t}}=\frac{K_{i t}}{\sum_{m=1}^{M} K_{m t}}=\frac{H_{i t}}{\sum_{m=1}^{M} H_{m t}} \quad i=1, \ldots, M
$$

Hence, with perfect capital mobility and similar technology, each economy's share of total FIE output, and each economy's share of total FIE physical capital stock, equals its share of the total FIE stock of human capital.

Relationship (8) has an important implication. It contrasts the policies pursued in isolation by any given FIE member with those that are instead pursued jointly (harmonized) across members. For example, (8) remains unchanged when a coordinated educational policy by all FIE members increases their human capital by the same proportion. In contrast, the same policy implemented by only one member increases that member's share of total FIE human capital (as long as this policy is not imitated by other members). Hence, if FIE members have harmonized economic and social policies (e.g., fiscal, education, industrial policies) then the equal-share property implies that the relative performance of each member remains unaffected by these policies. In this sense, member shares can be considered to be a random variable whose outcome is dependent on the particular state of nature at time $t$. Such randomness can easily be understood from the fact that various kinds of random shocks, like discoveries, weather, or natural disasters, including some that are specific to a particular member, would give rise to new and different sets of shares for all members. 
A rank-share distribution describes a particular relationship between the share and rank of a variable across a set of observational units. It is related to the concept of a rank-size distribution. For instance, a rank-size distribution for city size exists if the relationship between the natural logarithm of size and of rank is linear and exhibits a negative slope. Zipf's law arises when the slope value equals -1 .

The existence of Zipf's law for city sizes is a widely documented empirical regularity. ${ }^{4}$ Several explanations have been advanced for the observed regularity of Zipf's law with respect to the distribution of city sizes. Some argue it constitutes an optimal spatial pattern that arises when congestion and urbanization externalities interact as part of the process of development and growth of cities. Such forces are usually found in core models of urban and regional growth ${ }^{5}$. Others have stressed more mechanical forces that often involve a random growth process for city size. A recent example is Gabaix (1999a), who draws on Gibrat's law $^{6}$ to assume that cities follow a random but common growth process. Normalizing city population by a country's total population, Gabaix shows (his Proposition 1) that if population shares evolve as geometric Brownian motion with an infinitesimal barrier then the steady state distribution of population shares will be a rank-size distribution that exhibits Zipf's law.

As previously noted, the equal-share property for members of an FIE, together with an assumed harmonization of FIE member's economic policies, implies that the relative performance of any one FIE member can be considered a random variable. Given this, we can adopt Gabaix's (1999a) specification and assume that the share of variable $j$ (e.g., $j=$

\footnotetext{
${ }^{4}$ See e.g. Brakman et al. (2001), Fujita et al. (1999), Gabaix (1999b), Gabaix and Ioannides (2004), Eeckhout (2004) and Rose (2005).

${ }^{5}$ For example, see Eaton and Eckstein (1997), Black and Henderson (1999), Brakman et al. (1999).

${ }^{6}$ Gibrat's law (Gibrat, 1931) states that firm growth is independent of firm size.
} 
output) evolves as geometric Brownian motion with a lower bound ${ }^{7}$, and moreover, that the distribution of growth rates of these shares is common to all FIE members (i.e., Gibrat's law). ${ }^{8}$ As in Gabaix (1999a), this implies that the limiting distribution of the shares of variable $j$ across FIE members will be a rank-share distribution that exhibits Zipf's law.

\section{Empirical Specification}

Consider a FIE consisting of $M$ members. Let $S_{m j}$ denote member $m$ 's share of the total FIE amount of variable $j(j=$ output $(y)$, physical capital $(k)$ or human capital $(h))$ and let $R_{m j}$ denote the rank of member $m$ in the ranking of shares of variable $j$ across all members ( $m=1, \ldots, M)$. We assume $R_{m j}=1$ for the member with the largest share of variable $j$ and $R_{m j}$ $=M$ for the member with the lowest share of variable $j$. If variable $j$ has a rank-share distribution then we can write:

$$
S_{m j}=\gamma_{j}\left(R_{m j}\right)^{\beta_{j}}
$$

where $\beta_{j}<0$ is the power-law exponent and $0<\gamma_{j}<1$ is the share of variable $j$ for the member with the highest rank (i.e., $R_{m j}=1$ ). Zipf's law corresponds to $\beta_{j}=-1$, and it implies a specific relationship among member shares, namely: $S_{1 j}=2 S_{2 j}=3 S_{3 j}=\ldots=M S_{M j}$. This states, for example, that the share value of the highest ranked country is twice the share value of the second ranked country.

To empirically assess the hypothesis that output and factor shares conform to a rankshare distribution that exhibits Zipf's law we can take the natural logarithm of each side of (9) to obtain:

\footnotetext{
${ }^{7}$ One needs to prevent output and factors from falling below some lower bound in order to obtain a power law. Otherwise the distribution would be lognormal. A lower bound makes sense in integrated areas as important income transfers are institutionalized to prevent states/regions/countries to vanish. For example, the E.U. maintains a social fund and a regional fund.

${ }^{8}$ The equal-share relationship implies that the common expected rate of growth is zero since the sum over $\mathrm{i}$ of the output and factor shares in (8) must be 1.
} 


$$
\log \left(S_{m j}\right)=\theta_{j}+\beta_{j} \log \left(R_{m j}\right)+u_{m j} \quad m=1, \ldots, M ; j=y, k, h
$$

where $\theta_{j}=\log \left(\gamma_{j}\right)<0$ and $u_{m j}$ is an error term assumed to have the usual properties (i.e., i.i.d. with mean zero and constant variance). Estimates of the intercept and of the slope parameter in (10) are crucial to our analysis and are obtained by regressing the share of variable $j$ on variable $j$ 's rank value across FIE members.

We estimate (10) separately for the output share, physical capital share and human capital share with respect to the 51 U.S. states and the 14 E.U. countries. For U.S. states, we use annual cross-section data covering the period from 1990 to 2000. For E.U. countries the data instead consist of cross-sections equally spaced at 5-year intervals; these data generally cover the period from 1965 to 2000. A data appendix gives a complete description of data methods and sources.

Given estimates of (10) for a given dependent variable, evidence against Zipf's law can be assessed by testing if the estimated slope coefficient is significantly different from minus one. However, Gabaix and Ioannides (2004) and Nishiyama and Osada (2004) recently demonstrate that both the OLS estimate of $\beta_{j}$ in (10) and its associated standard error are expected to be biased downward, with these biases diminishing as the number of observational units $(M)$ increases. Hence, without some correction for these inherent biases, one is likely to more often reject Zipf's law when it is in fact true.

To correct for these biases, we follow Gabaix and Ioannides (2004, p. 10) and conduct, for the cases $M=14$ (E.U. countries) and $M=51$ (U.S. States), a Monte Carlo analysis of the OLS slope estimates derived from (10) under the assumption that Zipf's law holds. ${ }^{9}$ The difference between the true slope value $(-1)$ and the average of the OLS slope

\footnotetext{
${ }^{9}$ Briefly, for a given sample size $M$ (either $M=14$ or $M=51$ ), 100,000 Monte Carlo simulations are performed drawing from an exact power law with coefficient 1 (Zipf's Law). This involved drawing $M$ i.i.d. variables $v_{m}$, uniformly distributed in the interval $[0,1]$, and then constructing sizes $L_{m}=1 / v_{m}$. The sizes $L_{m}$ are then normalized into shares $S_{m}$ that were then ordered and assigned a rank value $R_{m}$. We then perform 100,000 OLS
} 
estimates gives an estimate of the downward bias, which is 0.172 for $M=14$ and 0.081 for $M$ $=51$. Given these estimates of the bias for each $M$, an estimate of the true slope coefficient is obtained by adding the estimated bias to the OLS estimate derived from (10).

To obtain a bias adjusted estimate of the standard error we follow Nishiyama and Osada (2004) and use the asymptotic approximation to the true standard error of the OLS slope estimate given as $-\hat{\beta}_{j} \sqrt{2 / M}$, where $\hat{\beta}_{j}$ is the OLS estimate of the slope in (10). ${ }^{10}$ The test statistic formed using these bias corrected values has asymptotically a normal distribution (Nishiyama and Osada, 2004).

\section{Results}

The first two columns of Table 1 report OLS estimates of (10) for the share of output, physical capital and human capital for the sample of U.S. states; the first two columns of Table 2 report the OLS estimates for the sample of E.U. countries. ${ }^{11}$ Over both set of results, the adjusted $R$-squares fall in the range from 0.791 to 0.945 , indicating a strong relationship between the share and rank of each variable.

In Table 1, the column labeled "Z-statistic Testing Slope $=-1$ " indicates strong support for the hypotheses that the output and factor shares for U.S. states conform to a rankshare distribution that exhibits Zipf's law; in no case can we reject (at the 5\% level) the hypothesis that the slope coefficient is significantly different from -1 . This is strong evidence that, for U.S. States, each of the three share distributions exhibit Zipf's law.

\footnotetext{
regressions using the specification $\log \left(S_{m}\right)=\theta+\beta \log \left(R_{m}\right)+u_{i}$. The complete results are available from the authors upon request.

${ }^{10}$ Another method for estimating the parameters of a power law distribution is the maximum likelihood Hill estimator (Hill, 1975). However, as Gabaix and Ioannides (2004) remark, the properties of the Hill estimator in finite samples can be "very worrisome," and in particular their theoretical results predict a large bias in parameter estimates and associated standard errors in small samples. We computed the Hill estimators (results not shown) and indeed found very high downward biases in both parameter estimates and standard errors.

${ }^{11}$ The standard errors associated with the OLS estimates are "robust" in the sense of White (1980).
} 
Table 1 - OLS Estimates of Rank-Share Relationships for U.S. States

\begin{tabular}{|c|c|c|c|c|c|}
\hline Variable & Year & Intercept $^{\mathrm{a}}$ & Slope $^{b}$ & $\begin{array}{l}\text { Z-statistic Testing } \\
\quad \text { Slope }=-1^{\mathrm{c}}\end{array}$ & $\underset{\mathbf{R}^{2}}{\operatorname{Adj} .}$ \\
\hline \multirow{11}{*}{$\begin{array}{c}\text { Output } \\
\text { Share } \\
(M=51)\end{array}$} & 1990 & $-1.179(0.248)$ & $-1.101(0.081)$ & -0.092 & 0.887 \\
\hline & 1991 & $-1.194(0.248)$ & $-1.093(0.081)$ & -0.055 & 0.884 \\
\hline & 1992 & $-1.199(0.252)$ & $-1.090(0.082)$ & -0.042 & 0.883 \\
\hline & 1993 & $-1.207(0.258)$ & $-1.085(0.084)$ & -0.019 & 0.881 \\
\hline & 1994 & $-1.208(0.265)$ & $-1.084(0.086)$ & -0.014 & 0.876 \\
\hline & 1995 & $-1.209(0.265)$ & $-1.083(0.086)$ & -0.009 & 0.874 \\
\hline & 1996 & $-1.205(0.267)$ & $-1.085(0.087)$ & -0.019 & 0.872 \\
\hline & 1997 & $-1.192(0.271)$ & $-1.091(0.088)$ & -0.046 & 0.868 \\
\hline & 1998 & $-1.173(0.272)$ & $-1.100(0.088)$ & -0.087 & 0.868 \\
\hline & 1999 & $-1.168(0.271)$ & $-1.103(0.088)$ & -0.101 & 0.866 \\
\hline & 2000 & $-1.164(0.266)$ & $-1.106(0.087)$ & -0.114 & 0.868 \\
\hline \multirow{11}{*}{$\begin{array}{c}\text { Physical } \\
\text { Capital } \\
\text { Share } \\
(M=51)\end{array}$} & 1990 & $-1.199(0.246)$ & $-1.092(0.080)$ & -0.051 & 0.892 \\
\hline & 1991 & $-1.207(0.247)$ & $-1.089(0.080)$ & -0.037 & 0.891 \\
\hline & 1992 & $-1.200(0.251)$ & $-1.092(0.081)$ & -0.051 & 0.892 \\
\hline & 1993 & $-1.197(0.257)$ & $-1.093(0.083)$ & -0.055 & 0.890 \\
\hline & 1994 & $-1.196(0.266)$ & $-1.092(0.086)$ & -0.051 & 0.884 \\
\hline & 1995 & $-1.173(0.275)$ & $-1.102(0.089)$ & -0.096 & 0.879 \\
\hline & 1996 & $-1.168(0.276)$ & $-1.105(0.089)$ & -0.110 & 0.878 \\
\hline & 1997 & $-1.126(0.286)$ & $-1.125(0.093)$ & -0.198 & 0.870 \\
\hline & 1998 & $-1.126(0.283)$ & $-1.126(0.091)$ & -0.202 & 0.876 \\
\hline & 1999 & $-1.108(0.283)$ & $-1.135(0.092)$ & -0.240 & 0.875 \\
\hline & 2000 & $-1.093(0.282)$ & $-1.143(0.091)$ & -0.274 & 0.880 \\
\hline \multirow{2}{*}{$\begin{array}{c}\text { Human } \\
\text { Capital } \\
\text { Share } \\
(M=\mathbf{5 1})\end{array}$} & 1990 & $-1.244(0.280)$ & $-1.064(0.091)$ & 0.081 & 0.854 \\
\hline & 2000 & $-1.264(0.293)$ & $-1.054(0.096)$ & 0.129 & 0.839 \\
\hline
\end{tabular}

${ }^{a}$ OLS standard errors in parentheses. All intercept coefficients significantly different from zero at $1 \%$ level.

${ }^{\mathrm{b}}$ OLS standard errors in parentheses. All slope coefficients significantly different from zero at $1 \%$ level.

${ }^{\mathrm{c}}$ Computed as the OLS slope estimate minus (- 1) plus 0.081 (the bias) divided by the asymptotic approximation of the true standard error (given as minus the OLS slope estimate times $\left.0.198=(2 / 51)^{0.5}\right)$. All slope coefficients are not significantly different from -1 at the $5 \%$ level. 
Table 2 - OLS Estimates of Rank-Share Relationships for E.U. Countries

\begin{tabular}{|c|c|c|c|c|c|}
\hline Variable & Year & Intercept $^{\text {a }}$ & Slope ${ }^{b}$ & $\begin{array}{l}\text { Z-statistic Testing } \\
\quad \text { Slope }=-1^{\text {c }}\end{array}$ & Adj. $R^{2}$ \\
\hline \multirow{9}{*}{$\begin{array}{c}\text { Output } \\
\text { Share } \\
(M=14)\end{array}$} & 1960 & $-0.645(0.397)$ & $-1.461(0.192)$ & -0.523 & 0.908 \\
\hline & 1965 & $-0.665(0.416)$ & $-1.435(0.204)$ & -0.485 & 0.889 \\
\hline & 1970 & $-0.699(0.433)$ & $-1.406(0.212)$ & -0.440 & 0.867 \\
\hline & 1975 & $-0.742(0.435)$ & $-1.366(0.211)$ & -0.376 & 0.859 \\
\hline & 1980 & $-0.755(0.419)$ & $-1.357(0.202)$ & -0.361 & 0.870 \\
\hline & 1985 & $-0.763(0.417)$ & $-1.354(0.199)$ & -0.356 & 0.872 \\
\hline & 1990 & $-0.772(0.420)$ & $-1.346(0.198)$ & -0.342 & 0.872 \\
\hline & 1995 & $-0.777(0.405)$ & $-1.343(0.187)$ & -0.337 & 0.878 \\
\hline & 2000 & $-0.857(0.376)^{*}$ & $-1.272(0.170)$ & -0.208 & 0.885 \\
\hline \multirow{8}{*}{$\begin{array}{c}\text { Physical } \\
\text { Capital } \\
\text { Share } \\
(M=14)\end{array}$} & 1965 & $-0.816(0.417)$ & $-1.293(0.217)$ & -0.248 & 0.851 \\
\hline & 1970 & $-0.825(0.396)$ & $-1.275(0.208)$ & -0.214 & 0.858 \\
\hline & 1975 & $-0.836(0.388)^{*}$ & $-1.262(0.203)$ & -0.189 & 0.858 \\
\hline & 1980 & $-0.760(0.484)$ & $-1.332(0.245)$ & -0.318 & 0.828 \\
\hline & 1985 & $-0.732(0.404)^{*}$ & $-1.358(0.205)$ & -0.362 & 0.870 \\
\hline & 1990 & $-0.670(0.398)$ & $-1.418(0.206)$ & -0.459 & 0.873 \\
\hline & 1995 & $-0.632(0.330)$ & $-1.457(0.174)$ & -0.518 & 0.908 \\
\hline & 2000 & $-0.658(0.382)$ & $-1.431(0.186)$ & -0.479 & 0.904 \\
\hline \multirow{9}{*}{$\begin{array}{c}\text { Human } \\
\text { Capital } \\
\text { Share } \\
(M=14)\end{array}$} & 1960 & $-0.147(0.448)$ & $-2.103(0.287)$ & -1.171 & 0.791 \\
\hline & 1965 & $-0.343(0.341)$ & $-1.890(0.184)$ & -1.005 & 0.880 \\
\hline & 1970 & $-0.529(0.280)^{*}$ & $-1.639(0.176)$ & -0.754 & 0.865 \\
\hline & 1975 & $-0.642(0.236)^{* *}$ & $-1.518(0.126)$ & -0.603 & 0.928 \\
\hline & 1980 & $-0.683(0.239)^{* *}$ & $-1.433(0.122)$ & -0.482 & 0.933 \\
\hline & 1985 & $-0.747(0.185)^{* *}$ & $-1.409(0.092)$ & -0.445 & 0.945 \\
\hline & 1990 & $-0.895(0.191)^{* *}$ & $-1.241(0.112)$ & -0.147 & 0.912 \\
\hline & 1995 & $-0.897(0.201)^{* *}$ & $-1.225(0.115)$ & -0.114 & 0.912 \\
\hline & 2000 & $-0.905(0.196)^{* *}$ & $-1.215(0.110)$ & -0.094 & 0.919 \\
\hline
\end{tabular}

${ }^{a}$ OLS standard errors in parentheses. Significantly different from zero at $* *=p<0.05$ or $*=p<0.10$

${ }^{\mathrm{b}}$ OLS standard errors in parentheses. All slope coefficients significantly different from zero at the $1 \%$ level.

${ }^{\mathrm{c}}$ Computed as the OLS slope estimate minus (-1) plus 0.172 (the bias) divided by the asymptotic approximation of the true standard error (given as minus the OLS slope estimate times $\left.0.3779=(2 / 14)^{0.5}\right)$. All slope coefficients are not significantly different from -1 at the $5 \%$ level. 
Likewise, the column labeled "Z-statistic Testing Slope $=-1$ " in Table 2 indicates also strong support for the hypotheses that the output and factor shares for E.U. countries conform to a rank-share distribution that exhibits Zipf's law: we cannot reject (at 5\% level) the hypothesis that the slope coefficient is significantly different from -1 . These findings for U.S. states and for E.U. countries are striking empirical results. ${ }^{12}$

\section{Further Characterization of Integrated Economies}

The empirical findings of the preceding section have further implications regarding the characterization of integrated economies. One implication is the potential empirical validity of the equal-share relationship as derived in (8) since, if Zipf's Law holds, the output shares across countries, or shares of any given factor, are proportional. Hence, if the equalshare relationship holds for one country then it must then also hold for all other countries. A second implication is that if Zipf's Law holds then the limiting share values across FIE members are completely determined once the number of FIE members is specified.

\section{Equal-share Relationship}

A test for the equal-share relationship involves the null hypothesis given by equation (8) against the alternative hypothesis given by (7). Evidence in favor of the equal-share relationship can be obtained in two steps: (1) test for homogeneity of the OLS slope estimates (i.e., whether $\beta_{y}=\beta_{k}=\beta_{h}$ ) to verify that the distributions of shares come from a common power-law distribution and (2) test for homogeneity of the intercepts across the three share equations (i.e., whether $\theta_{y}=\theta_{k}=\theta_{h}$ ) to examine if the equal-share relationship holds with respect to the highest ranked member of each FIE (i.e., California for U.S. states and

\footnotetext{
${ }^{12}$ By comparison, we preformed similar tests for 30 developing countries and a "world" of 55 countries but no evidence of Zipf's law was found at the usual significance levels.
} 
Germany for E.U. countries). ${ }^{13}$ Failure to reject the null hypothesis would imply that technological differences and factor market imperfections are not strong enough to prevent the equal-share relationship from holding in a statistical sense.

Table 3 - Results Testing the Equal-Share Relationship

\begin{tabular}{|c|c|c|c|}
\hline \multirow{2}{*}{ Integrated Economy } & \multirow{2}{*}{ Year } & \multicolumn{2}{|c|}{$\begin{array}{c}\text { p-values for testing across-equation } \\
\text { homogeneity of }\end{array}$} \\
\cline { 2 - 4 } & & intercepts & slopes \\
\hline \multirow{3}{*}{ U.S. States } & 1990 & 0.9680 & 0.9014 \\
\cline { 2 - 4 } & 2000 & 0.8241 & 0.5964 \\
\hline \multirow{4}{*}{ European Union } & 1965 & 0.6063 & $0.0445^{\text {a }}$ \\
\cline { 2 - 4 } & 1970 & 0.8011 & 0.2797 \\
\cline { 2 - 4 } & 1975 & 0.8619 & 0.3655 \\
\cline { 2 - 4 } & 1980 & 0.9689 & 0.8461 \\
\cline { 2 - 4 } & 1985 & 0.9969 & 0.9305 \\
\cline { 2 - 4 } & 1990 & 0.8111 & 0.6034 \\
\cline { 2 - 4 } & 1995 & 0.7124 & 0.3697 \\
\hline & 2000 & 0.7291 & 0.4072 \\
\hline
\end{tabular}

${ }^{a}$ Cross-equation homogeneity rejected at 5\% level.

Table 3 reports $p$-values for testing the hypotheses of slope homogeneity and of intercept homogeneity across the three share distributions in each sample year. ${ }^{14}$ For U.S. states, in neither of the two years for which data are available on all three shares (1990 and

\footnotetext{
${ }^{13}$ Equally, it can be demonstrated that the equal-share property obtains if one assumes 1) that output shares alone exhibit Zipf's law and 2) that FIE members have identical, homogenous of degree one, production functions.

${ }^{14}$ These tests are performed by establishing, in each year, a system comprising the three share equations but without initially imposing any cross-equation parameter restrictions.
} 
2000) can we reject the hypotheses of intercept equality and slope equality, supporting the equal-share relationship for U.S. states. The results for E.U. countries also indicate support for the equal-share relationship. These test results are based on slope estimates uncorrected for bias. However, correcting for the expected downward bias would only strengthen the support for the equal-share relationship evidenced here.

\section{Limiting Distribution of Shares}

Let $V_{m j}$ denote the level of variable $j$ for member $m$. Assume, without loss of generality, that member 1 has the highest value of variable $j$ and let $\delta_{m j}$ be member $m$ 's value of variable $j$ relative to that of member 1 (i.e., $\delta_{m j}=V_{m j} / V_{l j}$ ), so that $\delta_{1 j}=1$. Now order the values of variable $j$ in descending order. This ordering of the values of variable $j$ across the $m=1, \ldots, M$ members can be written:

$$
V_{l j}>\delta_{2 j} V_{l j}>\delta_{3 j} V_{1 j}>\ldots>\delta_{M j} V_{l j}
$$

Since the total FIE amount of variable $j$ is $\left(1+\delta_{l j}+\delta_{2 j}+\ldots+\delta_{M j}\right) V_{l j}$, (11) implies the following relations between member ranks and shares:

$$
\begin{gathered}
\operatorname{Rank} 1: S_{1 j}=\frac{1}{1+\delta_{2 j}+\delta_{3 j}+\ldots+\delta_{M j}} ; \\
\operatorname{Rank} 2: S_{2 j}=\frac{\delta_{2 j}}{1+\delta_{2 j}+\delta_{3 j}+\ldots+\delta_{M j}}
\end{gathered}
$$

Expressions (12) indicate that sequence of shares $S_{m j}$ is a Harmonic series, where each share value $S_{m j}$ depends on the values of the $\delta$ 's and the number of members $M$. Accepting our preceding empirical evidence that the distribution of shares exhibits Zipf's law then $\delta_{2 j}=1 / 2, \delta_{3 j}=1 / 3, \delta_{4 j}=1 / 4$, etc., so that the theoretical shares in (12) can be computed once 
the number of members $(M)$ is specified. For example, the theoretical share values for the $M$ $=51$ U.S. states are: $0.2213,0.1106,0.0738,0.0553, \ldots, 0.0043 . \quad$ For the $M=14$ E.U. countries the theoretical share values are: $0.3075,0.1538,0.1025,0.0769, \ldots, 0.0220$.

We conduct correlation and graphical analyses to gain insight on whether the observed distribution of shares conforms to the theoretically expected distribution of shares computed using (12). The relationship between actual shares and those computed from (12) is investigated in Table 4 which reports simple correlation coefficients between the natural logarithms of these shares for U.S. states and E.U countries in 1990 and 2000. The correlations range from 0.9176 to 0.9619 and all are highly significant, indicating a strong positive relationship between actual and theoretical shares.

Table 4 - Correlations between Logarithm of Actual and Theoretical Output and Factor Shares for U.S. States and E.U. Countries, 1990 and 2000

\begin{tabular}{|c|c|c|c|c|}
\hline \multirow{2}{*}{$\begin{array}{c}\text { Integrated } \\
\text { Economy }\end{array}$} & \multirow{2}{*}{ Year } & \multicolumn{3}{|c|}{$\begin{array}{c}\text { Correlation Between Logarithm of Actual Shares and } \\
\text { Theoretical Shares of }\end{array}$} \\
\cline { 3 - 5 } & & Output & Physical Capital & Human Capital \\
\hline \multirow{2}{*}{ U.S. States } & 1990 & 0.9429 & 0.9456 & 0.9258 \\
\cline { 2 - 5 } & 2000 & 0.9332 & 0.9393 & 0.9176 \\
\hline \multirow{2}{*}{$\begin{array}{c}\text { European } \\
\text { Union }\end{array}$} & 1990 & 0.9392 & 0.9397 & 0.9397 \\
\cline { 2 - 5 } & 2000 & 0.9453 & 0.9548 & 0.9619 \\
\hline
\end{tabular}


Figure 1: Theoretical and Actual Share Distributions for U.S. States and E.U. Countries

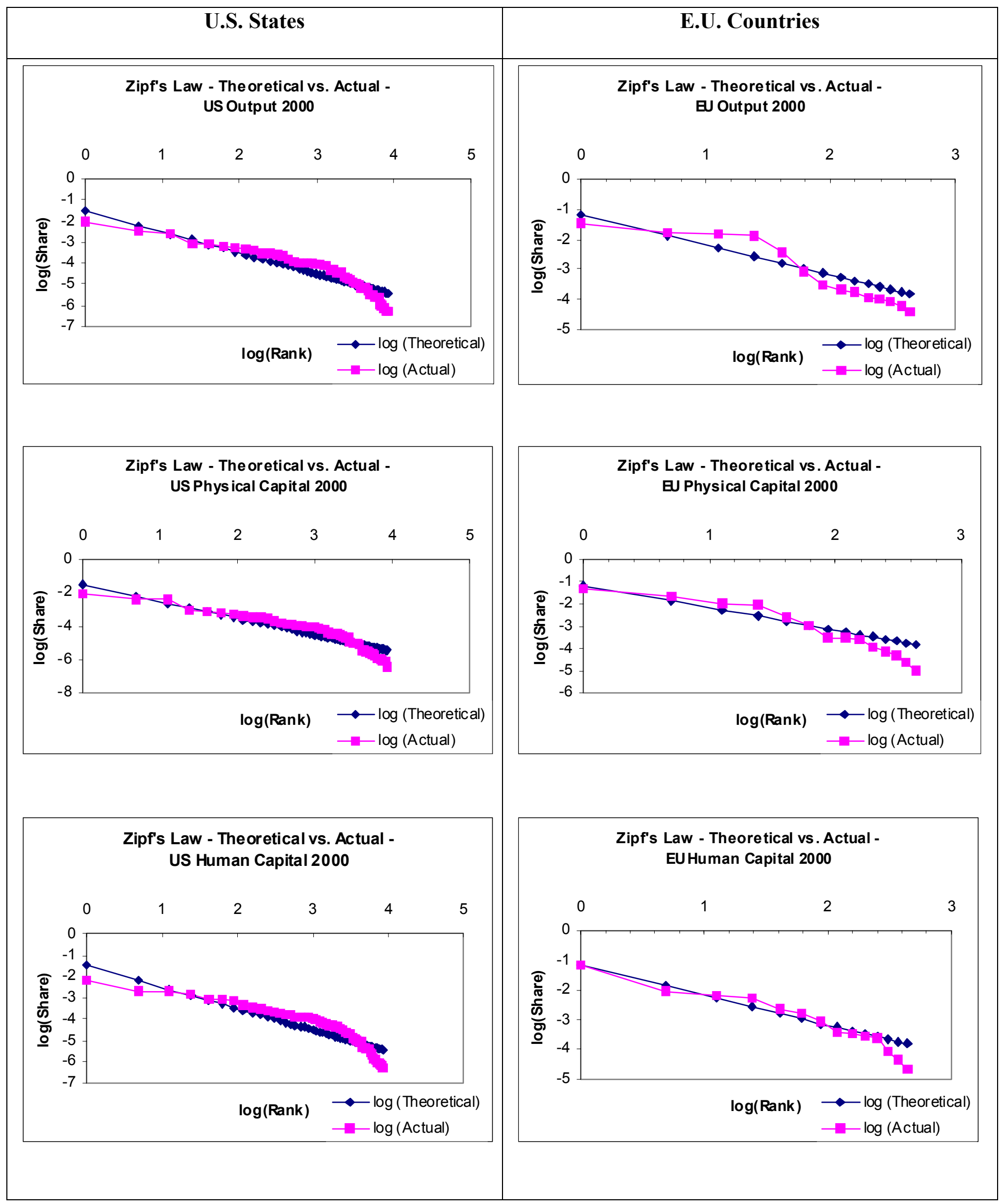


Figure 1 provides a graphical presentation of the share distributions by plotting the logarithm of the theoretically expected shares assuming Zipf's law holds and the logarithm of the actual shares in 2000 for each integrated economy. By definition, the theoretical shares (in logs) lie on a straight line with slope -1. Examination of the figures indicates that similar patterns between actual and theoretical shares appear for all three variables, whether for U.S. states or for E.U. countries. For example, for U.S. states, the graphs indicate that the share for the first observation (rank 1) is below the theoretical first share while in the middle range of the distribution the actual share is above the theoretical share. For E.U. countries the actual first share is instead very close to the theoretical share.

There are several explanations for the observed deviation in actual share values from their theoretical values. One is that the theoretical share distribution is a steady state prediction and our sample values may not represent this ideal. Another is that our theoretical model assumes that each FIE is "closed," in that goods and factor flows arise only between FIE members. In reality, both U.S. states and E.U. countries have important trade and factor flow linkages with entities outside these defined integrated economies. A third is that, since the shares for a given variable sum to unity across observations, the sum of their differences at each rank (i.e., the "residual") must be zero. Hence, the sum of any positive "residuals" must be offset by the sum of negative "residuals." To an approximation, this same result will hold for the sum of the difference between the shares at each rank when measured in logarithms.

\section{Discussion}

We examined empirically for evidence that the distribution of output and factor shares exhibit Zipf's law with respect to two integrated economies: the 51 U.S. states and 14 E.U. countries. The findings indicate that Zipf's law indeed holds for the distribution of these shares among U.S. states and also among E.U. countries. While there may be several 
explanations for this empirical finding, the evidence on the empirical significance of Zipf's law is consistent with a model that assumes that the growth process of the shares of members of an integrated economy is random and homogeneous across members.

Our empirical results also supported the existence of the equal-share relationship for both U.S. states and E.U. countries. This evidence leads to several implications regarding the characterization of integrated economies. First, the equal-share relationship addresses Lucas' (1990) question as to why capital does not flow from rich to poor countries. Namely, an economy with a low level (and hence a low share) of human capital will also have a low share of physical capital, and also a low share of output. Second, if the equal-share relationship holds, then all members of an integrated economy will have the same output per efficiency unit of labor. This implication is the essence of the absolute convergence hypothesis (Barro and Sala-i-Martin, 2004, p.47), here interpreted in terms of efficiency units of labor, not in per capita terms. Finally, the empirical significance of the equal-share relationship is consistent with the relative growth performance of members of an integrated economy being largely random, and hence strongly dependent on particular states of nature. Such randomness will be more true the greater the extent of economic integration among members, perhaps most exemplified by the integrated economy comprising U.S. states. Hence, it is more likely to be true the more harmonized are education systems and fiscal codes, when members do not run independent monetary policies, and when industrial policies are quickly imitated across members.

We also derived the result that, when Zipf's law holds, the values of the output and factor shares for members of a fully integrated economy are completely determined once the number of members is specified. These shares are limiting values that derive from the relative position (rank) of each member and would be expected to emerge as integrated 
economies approach full integration. Nonetheless, a comparison of actual share values to these theoretically expected share values indicated a high degree of agreement.

In providing evidence for Zipf's law and the equal-share relationship with respect to members of an integrated economy, this paper indicates that these empirical characterizations should be kept in mind when studying the implications of alternative policies on the relative growth of members of an integrated economic area. 


\section{References}

Baldwin, R. and P. Martin, 2004, “Agglomeration and Regional Growth,” in Henderson, J.V. and Thisse, J.-F. (Eds.), Handbook of Regional and Urban Economics-Volume IV (Amsterdam: North-Holland), Chapter 2.

Barro, R. J., 1999, “Determinants of Democracy,” Journal of Political Economy 107, S158S183.

Barro, R. J. and J.W. Lee, 1993, "International Comparisons of Educational Attainment," Journal of Monetary Economics 32, 363-394.

Barro, R. J. and J.W. Lee, 1996, "International Measures of Schooling Years and Schooling Quality," American Economic Review 86, 218-223.

Barro, R. J. and J.W. Lee, 2000, "International Data on Educational Attainment: Updates and Implications," Center for International Development Working Paper 42, Harvard University.

Barro, R. J. and X. Sala-i-Martin, 2004, Economic Growth (Cambridge, MA: MIT Press).

Black, D. and V. Henderson, 1999, "A Theory of Urban Growth," Journal of Political Economy 107, 252-284.

Bowen, H. P., E. E. Leamer and L. Sveikauskas, 1987, "Multicountry Multifactor Tests of the Factor Abundance Theory," American Economic Review, 77 (5), 791-809.

Brakman, S., H. Garretsen and C. van Marrewijk, 2001, An Introduction to Geographical Economies (Cambridge: Cambridge University Press).

Brakman, S. and M. van den Berg (1999), The Return of Zipf: Towards a further understanding of the Rank-Size Rule, Journal of Regional Science, 39, 183-213.

Devereux, M.B. and B.J. Lapham, 1994, "The Stability of Economic Integration and Endogenous Growth," Quarterly Journal of Economics 109(1), 299-308. 
Easterly, W. and R. Levine, 1998, “Africa's Growth Tragedy: Policies and Ethnic Divisions,” Quarterly Journal of Economics 112, 1203-1250.

Eaton, J. and Z. Eckstein, 1997, "Cities and Growth: Theory and Evidence from France and Japan," Regional Science and Urban Economics 27, 443-474.

Eeckhout, J., 2004, “Gibrat's Law for (All) Cities”, American Economic Review, 94(5), 14291451.

Fujita, M., P.R. Krugman and A.J. Venables, 1999, The Spatial Economy: Cities, Regions, and International Trade (Cambridge, Mass.: MIT Press).

Gabaix, X., 1999a, “Zipf’s Law for Cities: An Explanation,” Quarterly Journal of Economics 114(4), 739-767.

Gabaix, X., 1999b, "Zipf's Law and the Growth of Cities," American Economic Review 89(2), 129-132.

Gabaix, X. and Y. M. Ioannides, 2004, “The Evolution of City Size Distributions," in Henderson, J. V. and Thisse, J.-F. (Eds.), Handbook of Regional and Urban EconomicsVolume IV (Amsterdam: North-Holland), Chapter 7.

Garofalo, G. and S. Yamarik, 2002, "Regional Convergence: Evidence from a New State-byState Capital Stock Series”, Review of Economics and Statistics 82, 316-323.

Gibrat, R., 1931, Les Inegalites Economiques, (Paris: Librairie du Recueil Sirey).

Grossman, G.M., and E. Helpman, 1991, Innovation and Growth in the Global Economy (Cambridge: MIT Press).

Hall, R.E. and C. I. Jones, 1999, "Why Do Some Countries Produce So Much More Output Per Worker than Others?," Quarterly Journal of Economics 114, 83-116.

Helpman, E. and P. Krugman (1985): Market Structure and Foreign Trade, (Cambridge MA: MIT Press). 
Heston, A. and R. Summers, 1991a, "The Penn World Table (Mark 5): An Expanded Set of International Comparisons, 1950-1988," Quarterly Journal of Economics 106, 327-368.

Heston, A. and R. Summers, 1991b, Penn World Table Version 5.6, Center for International Comparisons at the University of Pennsylvania (CICUP).

Heston, A. and R. Summers and B. Aten, 2002, Penn World Table Version 6.1, Center for International Comparisons at the University of Pennsylvania (CICUP).

Hill, B. M., 1975, "A Simple Approach To Inference About The Tail Of A Distribution", Annals of Statistics 3, 1163-1174.

Leamer, E. E., 1984, Sources of International Comparative Advantage: Theory and Evidence. Cambridge, MA : MIT Press.

Lucas, R. E., 1990, “Why Doesn't Capital Flow from Rich to Poor Countries?” American Economic Review 80, 92-96.

Mankiw, M.G., D. Romer and D. M. Weil, 1992, "A Contribution to the Empirics of Economic Growth," Quarterly Journal of Economics 107, 407-437.

Munnell, A., 1990, "Why Has Productivity Growth Declined? Productivity and Public Investment," New England Economic Review, 407-438.

Nishiyama, Y. and S. Osada, 2004, "Statistical Theory of Rank Size Rule Regression under Pareto Distribution," Interfaces for Advanced Economic Analysis Discussion Paper, Kyoto University.

Rajan, R.G. and L. Zingales, 1998, "Financial Dependence and Growth," American Economic Review 88, 559-586.

Ramey, G., and V. A. Ramey, 1995, "Cross-country Evidence on the Link between Volatility and Growth," American Economic Review 85, 1138-1151.

Rivera-Batiz, L. and P. Romer, 1991, "Economic Integration and Endogenous Growth", Quarterly Journal of Economics 106(2), 531-555. 
Rose, A.K., 2005, “Cities and Countries,” NBER Working Paper 11762, (November).

Sachs, J. D. and A. Warner, 1995, "Economic Reform and the Process of Global Integration," Brookings Papers on Economics Activity, 1-95.

Timmer, M. P., G. Ypma, and B. van Ark, 2003, "IT in the European Union: Driving Productivity Divergence?" GGDC Research Memorandum GD-67, University of Groningen.

U.S. Bureau of Economic Analysis, 2002, Fixed Assets and Consumer Durable Goods for 1925-2001.

Viaene, J.-M., and Zilcha, I., 2002, "Capital Markets Integration, Growth and Income Distribution," European Economic Review 46, 301-327.

White, H., 1980, "A heteroskedasticity-consistent covariance matrix estimator and a direct test for heteroskedasticity," Econometrica 48, 817-838. 


\section{Appendix - Data Methods and Sources}

The output for each of the 51 U.S. states is measured by real gross state product as reported by the U.S. Bureau of Economic Analysis (BEA). ${ }^{15}$ These data are available yearly from 1990 to 2000 .

Estimates of state physical capital stocks are derived from BEA (2002) estimates of the total U.S. physical capital stock in each of nine one-digit industrial sectors comprising all economic activity. ${ }^{16}$ These national physical capital stocks in each industry are allocated to each state by multiplying an industry's total capital stock ${ }^{17}$ by that industry's contribution to a state's total income. ${ }^{18}$ These industry capital stock estimates are then summed, for each state, to obtain an estimate of a state's total stock of physical capital. ${ }^{19}$ The calculation performed for each state at each time $t$ can be expressed algebraically as

$$
k_{m}(t)=\sum_{j=1}^{9}\left[K_{j}(t)\left(y_{m j}(t) / Y_{m}(t)\right)\right]
$$

In this equation, $k_{m}(t)$ is the stock of physical capital in state $m, y_{m j}(t)$ is value added by industry $j$ in state $m(m=1 \ldots 51), Y_{m}(t)$ is state $m$ 's total value added, and $K_{j}(t)$ is the national level stock of physical capital in industry $j(j=1, \ldots, 9)$. This procedure assumes that the capital-to-output ratio within an industry $j$ (i.e., $\left.k_{m j}(t) / y_{m j}(t)\right)$ is the same across U.S. states, that is, $k_{m j}(t) / y_{m j}(t)=K_{m}(t) / Y_{m}(t)$. In turn, this assumption implies that an industry is in a common steady state across all U.S. states. ${ }^{20}$ For example, the agricultural sector in Texas is in the same steady state as its counterpart in Oregon, and the manufacturing sector in

\footnotetext{
${ }_{16}^{15}$ Data on gross state product available at http://www.bea.doc.gov/bea/regional/gsp

${ }^{16}$ The sectors (BEA code) are Farming (81), Agricultural services, forestry, fishing \& other (100); Mining (200); Construction (300); Manufacturing (400); Transportation(500); Wholesale and retail trade (610); Finance, insurance and real estate (700); and Services (800).

17 Data on state physical capital stocks by industry were taken from U.S. Fixed Assets Tables, available at http://www.bea.doc.gov/bea/dn/faweb

$\frac{18}{18}$ Annual data on state value added available at http://www.bea.doc.gov/bea/regional/spi

${ }^{19}$ This procedure follows that used by Munnel (1990) and Garofalo and Yamarik (2002).

${ }^{20}$ If a sector is converging towards its steady state, the output-to-capital ratio would be below its steady-state value. This only poses a problem if the initial output-to-capital ratios vary across U.S. states. If the ratios do vary, the procedure would allocate too much to those states further from steady-state and too little to those states closer to their steady state.
} 
Pennsylvania is in the same steady state as its counterpart in Ohio. ${ }^{21}$ The constructed physical capital data are from 1990 to 2000 , on a yearly basis.

Human capital stocks for U.S. states are proxied by the number of persons with at least secondary level education. They are derived from data on state educational attainment taken from the U.S. Bureau of the Census. ${ }^{22}$ Census data on educational attainment are available only every 10 years, which limited the construction of human capital stocks to two years: 1990 , and 2000.

For E.U. countries, each country's total output is measured by its real gross domestic product (GDP) derived from the data on real GDP per capita (base year $=1996$ ) and population in Penn World Tables 6.1 (Heston, Summers and Aten, 2002). The output data are available annually from 1960 to 2000 .

Data on E.U. physical capital stocks are derived from Penn World Tables 5.6 (Heston and Summers, 1991a and 1991b) which reports four data series for each country: (1) population, (2) physical capital stock per worker, (3) real GDP per capita and (4) real GDP per worker. The physical capital stocks for each country are constructed as the product of the first three series divided by the last series. The data covers the period 1965-1990. Physical capital stock data for E.U. countries are also available from Timmer et al. (2003) covering period $1980-2000 .^{23}$ These data sources are combined to have physical capital stock data in each of seven years from 1965 to $2000 .^{24}$

Each E.U. country's stock of human capital stock is measured by multiplying the percentage of a country's population having at least a secondary level of education with the

\footnotetext{
${ }^{21}$ If a sector has a different steady state, and hence a different capital-to-output ratio, the procedure will allocate too much to states with lower ratios and too little to states with higher ratios. However, this possibility is unlikely if competition lead firms in all states to adopt the best available production technology.

${ }^{22}$ Decennial Census dataset available at http://factfinder.census.gov

${ }^{23}$ Physical capital database available at http://www.ggdc.net/dseries/growth-accounting.shtml

${ }^{24}$ Estimation was conducted using both sets of data for E.U. countries. No qualitative difference in results was found for the years in which data were available from both sources (i.e., 1980, 1985 and 1990). For these three years we therefore report only the results using the capital stock data from Timmer et al. (2003).
} 
country's total population. Data on the rate of educational attainment for each country are taken from Barro and Lee $\left(1993,1996\right.$, and 2000). ${ }^{25}$ Data on a country’s population are from Heston, Summers and Aten (2002). Since data on rates of educational attainment are only available every 5 years, the data sample is limited to five-year intervals from 1960 to 2000 . Following this constraint, the output and physical capital stocks are also obtained in five-year intervals.

The 14 E.U. countries are: Austria, Belgium, Denmark, Finland, France, Germany, Greece, Ireland, Italy, Netherlands, Portugal, Spain, Sweden and United Kingdom. ${ }^{26}$

\footnotetext{
${ }^{25}$ Other studies using the Barro-Lee data include Rajan and Zingales (1998), Ramey and Ramey (1995), Barro (1999), Easterly and Levine (1998), Hall and Jones (1999) and Sachs and Warner (1995).

${ }^{26}$ Luxembourg is excluded for lack of data on human capital. Given the small scale of Luxembourg's economy relative to other E.U. countries this omission is unlikely to affect the E.U. results.
} 


\section{CESifo Working Paper Series}

(for full list see www.cesifo-group.de)

1681 Wladimir Raymond, Pierre Mohnen, Franz Palm and Sybrand Schim van der Loeff, Persistence of Innovation in Dutch Manufacturing: Is it Spurious?, March 2006

1682 Andrea Colciago, V. Anton Muscatelli, Tiziano Ropele and Patrizio Tirelli, The Role of Fiscal Policy in a Monetary Union: Are National Automatic Stabilizers Effective?, March 2006

1683 Mario Jametti and Thomas von Ungern-Sternberg, Risk Selection in Natural Disaster Insurance - the Case of France, March 2006

1684 Ken Sennewald and Klaus Waelde, “Itô’s Lemma“ and the Bellman Equation for Poisson Processes: An Applied View, March 2006

1685 Ernesto Reuben and Frans van Winden, Negative Reciprocity and the Interaction of Emotions and Fairness Norms, March 2006

1686 Françoise Forges, The Ex Ante Incentive Compatible Core in Exchange Economies with and without Indivisibilities, March 2006

1687 Assar Lindbeck, Mårten Palme and Mats Persson, Job Security and Work Absence: Evidence from a Natural Experiment, March 2006

1688 Sebastian Buhai and Coen Teulings, Tenure Profiles and Efficient Separation in a Stochastic Productivity Model, March 2006

1689 Gebhard Kirchgaessner and Silika Prohl, Sustainability of Swiss Fiscal Policy, March 2006

1690 A. Lans Bovenberg and Peter Birch Sørensen, Optimal Taxation and Social Insurance in a Lifetime Perspective, March 2006

1691 Moritz Schularick and Thomas M. Steger, Does Financial Integration Spur Economic Growth? New Evidence from the First Era of Financial Globalization, March 2006

1692 Burkhard Heer and Alfred Maussner, Business Cycle Dynamics of a New Keynesian Overlapping Generations Model with Progressive Income Taxation, March 2006

1693 Jarko Fidrmuc and Iikka Korhonen, Meta-Analysis of the Business Cycle Correlation between the Euro Area and the CEECs, March 2006

1694 Steffen Henzel and Timo Wollmershaeuser, The New Keynesian Phillips Curve and the Role of Expectations: Evidence from the Ifo World Economic Survey, March 2006

1695 Yin-Wong Cheung, An Empirical Model of Daily Highs and Lows, March 2006 
1696 Scott Alan Carson, African-American and White Living Standards in the $19^{\text {th }}$ Century American South: A Biological Comparison, March 2006

1697 Helge Berger, Optimal Central Bank Design: Benchmarks for the ECB, March 2006

1698 Vjollca Sadiraj, Jan Tuinstra and Frans van Winden, On the Size of the Winning Set in the Presence of Interest Groups, April 2006

1699 Martin Gassebner, Michael Lamla and Jan-Egbert Sturm, Economic, Demographic and Political Determinants of Pollution Reassessed: A Sensitivity Analysis, April 2006

1700 Louis N. Christofides and Amy Chen Peng, Major Provisions of Labour Contracts and their Theoretical Coherence, April 2006

1701 Christian Groth, Karl-Josef Koch and Thomas M. Steger, Rethinking the Concept of Long-Run Economic Growth, April 2006

1702 Dirk Schindler and Guttorm Schjelderup, Company Tax Reform in Europe and its Effect on Collusive Behavior, April 2006

1703 Françoise Forges and Enrico Minelli, Afriat's Theorem for General Budget Sets, April 2006

1704 M. Hashem Pesaran, Ron P. Smith, Takashi Yamagata and Liudmyla Hvozdyk, Pairwise Tests of Purchasing Power Parity Using Aggregate and Disaggregate Price Measures, April 2006

1705 Piero Gottardi and Felix Kubler, Social Security and Risk Sharing, April 2006

1706 Giacomo Corneo and Christina M. Fong, What's the Monetary Value of Distributive Justice?, April 2006

1707 Andreas Knabe, Ronnie Schoeb and Joachim Weimann, Marginal Employment Subsidization: A New Concept and a Reappraisal, April 2006

1708 Hans-Werner Sinn, The Pathological Export Boom and the Bazaar Effect - How to Solve the German Puzzle, April 2006

1709 Helge Berger and Stephan Danninger, The Employment Effects of Labor and Product Markets Deregulation and their Implications for Structural Reform, May 2006

1710 Michael Ehrmann and Marcel Fratzscher, Global Financial Transmission of Monetary Policy Shocks, May 2006

1711 Carsten Eckel and Hartmut Egger, Wage Bargaining and Multinational Firms in General Equilibrium, May 2006

1712 Mathias Hoffmann, Proprietary Income, Entrepreneurial Risk, and the Predictability of U.S. Stock Returns, May 2006 
1713 Marc-Andreas Muendler and Sascha O. Becker, Margins of Multinational Labor Substitution, May 2006

1714 Surajeet Chakravarty and W. Bentley MacLeod, Construction Contracts (or "How to Get the Right Building at the Right Price?”), May 2006

1715 David Encaoua and Yassine Lefouili, Choosing Intellectual Protection: Imitation, Patent Strength and Licensing, May 2006

1716 Chris van Klaveren, Bernard van Praag and Henriette Maassen van den Brink, Empirical Estimation Results of a Collective Household Time Allocation Model, May 2006

1717 Paul De Grauwe and Agnieszka Markiewicz, Learning to Forecast the Exchange Rate: Two Competing Approaches, May 2006

1718 Sijbren Cnossen, Tobacco Taxation in the European Union, May 2006

1719 Marcel Gérard and Fernando Ruiz, Interjurisdictional Competition for Higher Education and Firms, May 2006

1720 Ronald McKinnon and Gunther Schnabl, China's Exchange Rate and International Adjustment in Wages, Prices, and Interest Rates: Japan Déjà Vu?, May 2006

1721 Paolo M. Panteghini, The Capital Structure of Multinational Companies under Tax Competition, May 2006

1722 Johannes Becker, Clemens Fuest and Thomas Hemmelgarn, Corporate Tax Reform and Foreign Direct Investment in Germany - Evidence from Firm-Level Data, May 2006

1723 Christian Kleiber, Martin Sexauer and Klaus Waelde, Bequests, Taxation and the Distribution of Wealth in a General Equilibrium Model, May 2006

1724 Axel Dreher and Jan-Egbert Sturm, Do IMF and World Bank Influence Voting in the UN General Assembly?, May 2006

1725 Swapan K. Bhattacharya and Biswa N. Bhattacharyay, Prospects of Regional Cooperation in Trade, Investment and Finance in Asia: An Empirical Analysis on BIMSTEC Countries and Japan, May 2006

1726 Philippe Choné and Laurent Linnemer, Assessing Horizontal Mergers under Uncertain Efficiency Gains, May 2006

1727 Daniel Houser and Thomas Stratmann, Selling Favors in the Lab: Experiments on Campaign Finance Reform, May 2006

1728 E. Maarten Bosker, Steven Brakman, Harry Garretsen and Marc Schramm, A Century of Shocks: The Evolution of the German City Size Distribution 1925 - 1999, May 2006

1729 Clive Bell and Hans Gersbach, Growth and Enduring Epidemic Diseases, May 2006 
1730 W. Bentley MacLeod, Reputations, Relationships and the Enforcement of Incomplete Contracts, May 2006

1731 Jan K. Brueckner and Ricardo Flores-Fillol, Airline Schedule Competition: ProductQuality Choice in a Duopoly Model, May 2006

1732 Kerstin Bernoth and Guntram B. Wolff, Fool the Markets? Creative Accounting, Fiscal Transparency and Sovereign Risk Premia, May 2006

1733 Emmanuelle Auriol and Pierre M. Picard, Government Outsourcing: Public Contracting with Private Monopoly, May 2006

1734 Guglielmo Maria Caporale and Luis A. Gil-Alana, Modelling Structural Breaks in the US, UK and Japanese Unemployment Rates, May 2006

1735 Emily J. Blanchard, Reevaluating the Role of Trade Agreements: Does Investment Globalization Make the WTO Obsolete?, May 2006

1736 Per Engström and Bertil Holmlund, Tax Evasion and Self-Employment in a High-Tax Country: Evidence from Sweden, May 2006

1737 Erkki Koskela and Mikko Puhakka, Cycles and Indeterminacy in Overlapping Generations Economies with Stone-Geary Preferences, May 2006

1738 Saku Aura and Thomas Davidoff, Supply Constraints and Housing Prices, May 2006

1739 Balázs Égert and Ronald MacDonald, Monetary Transmission Mechanism in Transition Economies: Surveying the Surveyable, June 2006

1740 Ben J. Heijdra and Ward E. Romp, Ageing and Growth in the Small Open Economy, June 2006

1741 Robert Fenge and Volker Meier, Subsidies for Wages and Infrastructure: How to Restrain Undesired Immigration, June 2006

1742 Robert S. Chirinko and Debdulal Mallick, The Elasticity of Derived Demand, Factor Substitution and Product Demand: Corrections to Hicks' Formula and Marshall's Four Rules, June 2006

1743 Harry P. Bowen, Haris Munandar and Jean-Marie Viaene, Evidence and Implications of Zipf's Law for Integrated Economies, June 2006 